\title{
USE OF FORCE OR DIPLOMATIC INTERVENTION: ASSESSING THE BLOCKADE OF QATAR
}

\author{
Suleiman Usman Santuraki*
}

\begin{abstract}
The coordinated blockade of the State of Qatar by some of its neighbours in June 2017 has raised questions on the sovereignty of the state and the extent to which coercion is allowed in international law. This article considers the reasons behind the blockade and the subsequent demands by Qatar's neighbours. It evaluates the blockade of Qatar based on the twin principles of international law: the prohibition on the use of force and non-interference in the internal affairs of other nations. The article argues that the language of article 2 (4), read together with the purposes of the United Nations (UN), render any forcible attempt to coerce a sovereign state into surrendering its sovereignty illegal. The article also considers the debate on whether economic and political coercion amounts to force. It submits that the coordinated blockade and the subsequent "13 points" demands threaten Qatar's sovereignty, because the blockade contravenes the purposes of the UN. The article also argues that the blockade amounts to an interference in the internal affairs of Qatar, even if economic or political coercion are not considered as force. The article finds that the blockade does not categorically amount to a threat or use of force; but it certainly violates the principle of non-intervention as enshrined in the UN Charter.
\end{abstract}

Keywords: use of force, non-intervention, blockade on Qatar, sovereign state.

* Lecturer at Department of Public Law, University of Maiduguri, Nigeria. Email: suleisant@gmail.com.

[Received: 21 August 2019, Accepted: 19 March 2020, Published: 28 December 2020] 


\title{
PENGGUNAAN KEKERASAN ATAU CAMPUR TANGAN DIPLOMATIK: PENILAIAN SEKATAN TERHADAP QATAR
}

\begin{abstract}
ABSTRAK
Penyelarasan sekatan terhadap Qatar oleh beberapa negara jiran pada Jun, 2017 telah menimbulkan tanda tanya keatas kedaulatan negara dan sejauh mana ugutan dibenarkan oleh undang-undang antarabangsa. Artikel ini merungkai sebab-sebab di sebalik sekatan dan permintaan. Ia menilai sekatan terhadap Qatar berdasarkan prinsip-prinsip berkembar urusan negara-negara lain. Artikel ini berhujah bahawa bahasa artikel 2 (4) dibaca bersama tujuan-tujuan Pertubuhan Bangsabangsa Bersatu (PBB), melakukan percubaan secara ugutan terhadap negara berdaulat untuk menyerahkan kedaulatannya adalah salah. Artikel ini juga mempertimbangkan perbahasan sama ada ugutan ekonomi dan politik bersamaan dengan paksaan. Artikel ini berpendapat yang penyelarasan sekatan dan permintaan seterusnya "13 perkara" mengancam kedaulatan Qatar kerana sekatan tersebut menyalahi tujuan-tujuan PBB. Artikel ini juga berhujah bahawa sekatan tersebut bersamaan dengan campur tangan di dalam urusan dalaman Qatar walaupun ugutan ekonomi dan politik tidak dianggap sebagai paksaan. Artikel ini berpendapat yang sekatan tersebut tidak termasuk didalam kategori ugutan atau menggunakan paksaan, tetapi sewajarnya menyalahi prinsip tiada campur tangan sepertimana termaktub di dalam Piagam PBB.
\end{abstract}

Kata kunci: penggunaan kekerasan, tanpa campur tangan, sekatan terhadap Qatar, negara berdaulat.

\section{INTRODUCTION}

The coordinated blockade on the state of Qatar by a group of neighbouring Gulf States raises important questions in international law. Notably, the proscription of threat or resort to force, and the principle of non-interference in the domestic dealings of a state, constitute some of the most outstanding precepts of the United Nations (UN) system. States are prohibited from the use or threat of force against members of the UN. The prohibition proscribes force aimed at other states' territorial integrity or political independence. It includes threats or uses of force that violate the purposes of the UN. 
Such purposes include peaceful coexistence among states, maintenance of global amity and security, non-resort to force in international relations, and the advancement of economic and mutual progress of all nationalities. ${ }^{1}$ The ultimate values of the UN as an institution frown at ultimatums, threats, and unilateral alienation. These on the other hand, are the ideas behind the blockade against Qatar as reflected in the terms of the 13-point demands. The choice of the word "force" as opposed to war and the broad prohibition covering threat in addition to the use of force reinforces the prohibition. The clear pattern that emerged in 1945 is that the international community was poised to outlaw force in all its ramifications. The prohibited actions were required not to target the sanctity of a nation's territory nor the independence of its political structures. The aim was very clear: all actions aimed at the inviolability of a nation's territory or the independence of its political institutions, or actions which otherwise contravene the goals of the UN were proscribed.

The principle of non-interference is closely related to the prohibition against the use of force. The relationship between the two tenets accentuates their primary objective: respect and preservation of the honour and autonomy of states. The non-intervention principle, though devised in relation to the $\mathrm{UN}$ as an institution, has generally been recognised as applying to inter-state relations. ${ }^{2}$ It requires that states, big and small, weak and powerful, rich and poor, be accorded the right to take control of their domestic affairs, including their foreign relations in the way best suited to them. This principle emphasizes the right of states to choose their partners, be it economic, political, or otherwise. ${ }^{3}$ Simply put, states should respect such decisions as the sovereign will of the state concerned. Though influence may not be ruled out in international relations, it differs from coercion basically from the method used and the options available.

1 United Nations, "Charter Of The United Nations" (San Francisco, 1945), doi:ISBN: 9789210020251. Preamble.

2 Marcelo Kohen, "The Principle of Non-Intervention 25 Years after the Nicaragua Judgment," Leiden Journal of International Law 25, no. 1 (March 6, 2012): 158-159.

3 Ibid. 
This article therefore, reviews the coordinated blockade on Qatar by some of its neighbours in view of the prohibition against resort to force as well as the principle of non-interference in the internal matters of other nations. The paper starts with a background aimed at giving general information concerning the nature and objectives of the blockade. It then discusses the prohibition against the threat or use of force under the UN Charter, including the use of economic and political pressure as force. It further discusses the general settings on the principle of non-intervention under the UN Charter. Thereafter, the paper juxtaposes the facts of the blockade, especially the 13-points demand with the position of international law on the threat or resort to force and interference in the domestic affairs of a state, before concluding.

\section{BRIEF BACKGROUND OF THE BLOCKADE ON QATAR}

On June 5, 2017, the world woke up to a sudden and surprising announcement by Saudi Arabia, the UAE, Bahrain, and Egypt, (the blockading nations) that they have severed diplomatic ties with the state of Qatar. In addition, they also announced sweeping measures, comprising of economic, trade, and travel boycotts, as well as closure of their land, sea and airspace. Simply put, the measures amounted to total isolation of Qatar by its neighbours. Saudi Arabia, UAE and Bahrain restrained their citizens from traveling to Qatar in addition to giving Qatari citizens 14 days to leave their countries. Egypt however, placed no restrictions on its citizens living in Qatar. ${ }^{4}$ The reasons for the blockade came in phases as they unfold. Initially, it centred on statements supposedly published by Qatar's official news agency, which were later shown to be fake. ${ }^{5}$ On declaring the blockade however, the immediate reasons given were Qatar's support for terrorism. No tangible evidence was presented to that effect, ${ }^{6}$ and Qatar denied that it supports terrorism. Qatar has though, provided support to Islamic based groups such as the Muslim Brotherhood in

4 BBC NEWS, “Qatar Crisis: What You Need to Know," 19 July, 2017, www.bbc.com/news (last visited 28/11/2017.

5 Aljazeera, "Qatar to 'Prosecute Perpetrators' of QNA Hacking," 25 May, 2017, www.aljazeera.com/topics/country/qatar.html (last visited 28/11/2017).

6 BBC NEWS, "Qatar Crisis: What You Need to Know." 
Egypt. ${ }^{7}$ On June 22 2017, the blockading nations issued a thirteenpoint onerous list of demands to Qatar as condition to lift the blockade. ${ }^{8}$ Qatar responded that the demands amount to surrendering its sovereignty; ${ }^{9}$ a position not far from the truth as the list was generally seen as unrealistic. ${ }^{10}$

\section{THE PROHIBITION AGAINST THE THREAT OR USE OF FORCE}

Historically, war against other states was considered a part of national strategy without necessarily having to proffer reasons. As the harsh reality of war weighs down on modern states however, attempts were made to restrict, if not abolish wars among states. This move began to gain prominence with the 'just war' concept propounded by Roman and Greek philosophers. ${ }^{11}$ With his personal experience of the consequences of war, Grotius reformulated the just war concept to require that the state suffers an injury as opposed to mere contemplation of evil. ${ }^{12}$ The attempt to proscribe war under the League of Nations signalled the beginning of an era where war between states was no longer a popular issue. Though war was not categorically proscribed under the League of Nations, it invigorated pacific settlement of disagreements among nations. ${ }^{13}$ The inability of the League of Nations regime to thwart the Second World War led to the grand stand taken by the international community to categorically proscribe war under the UN Charter.

$7 \quad$ Ibid.

8 The Guardian, "Qatar given 10 Days to Meet 13 Sweeping Demands by Saudi Arabia," 23 June, 2017, https://www.theguardian.com/international (last visited 28/11/2017).

9 BBC NEWS, "Qatar Crisis: What You Need to Know."

10 The Guardian, "Qatar given 10 Days to Meet 13 Sweeping Demands by Saudi Arabia." Especially remarks by the UK foreign secretary.

11 Mohammad Naqib Ishan Jan, Use of Force in International Law (Selangor, Malaysia: The Malaysian Current Law Journal, 2011). 21.

12 Ibid.

13 League of Nations, "Covenant of the League of Nations," 1919. Articles $10-16$. 
Notably, in proscribing war, the UN Charter used the term "force" as opposed to "war". This was a deliberate move to curb the use of force by states, and encourage peaceful coexistence between states. It was also meant to assure smaller nations that their sovereignty and independence will be respected. The fact that article 2 (4) of the Charter prohibits not only the use, but also threat of force affirms this position. The prohibition as reflected in opinions of publicists and the jurisprudence of the International Court of Justice (ICJ) signify a generally acknowledged value of the international community. ${ }^{14}$ Since there is no contention that the threat and resort to force are proscribed; the issue would be what constitutes force.

\section{Economic and political pressure as force}

The history behind the wordings of article 2 (4) of the UN Charter indicates that the proscription was meant to safeguard the sanctity of territory and political structure of states..$^{15}$ Consequently, the word "force" within the context of article 2 (4) is capable of several interpretations - equally aimed at protecting the territorial integrity and political independence of states. Force certainly includes "armed force", though it is not restricted to that. There have been debates as to whether political or economic force is also proscribed under the UN Charter. ${ }^{16}$ Though the debate is far from being conclusive, a considerable number of writers believe that the prohibition covers only armed force. ${ }^{17}$ The arguments are based on considerations of other parts of the UN Charter such as articles 44, the preamble, and reasoned understandings. It is reasoned that accepting a prohibition on economic or political force will hinder the implementation of

14 Albrecht Randelzhofer and Oliver Dorr, "Article 2 (4)," in The Charter of the United Nations, ed. Bruno Simma, et al., 3rd ed. (Oxford: Oxford University Press, 2012). 207; see also ICJ Reports, Case Concerning Military and Paramilitary Activities in and Against Nicaragua (Merits) (1986). 14.

15 Mohammed Barakat, "The Legality of the Use of Force against Iraq in 2003" (City University London, 2007). 14-15.

16 Randelzhofer and Dorr, "Article 2 (4)." 208.

17 Yoram Dinstein, War, Aggression and Self-Defence, 4th ed. (Cambridge: Cambridge University Press, 2005). 86; see also Randelzhofer and Dorr, “Article 2 (4).” 208, fn. 28. 
international law in the absence of international organs which could effectively ensure that. ${ }^{18}$

However, while arguing for the restricted interpretation of article 2 (4), it is accepted that the use of economic and political coercion may contravene the rule on non-interference. ${ }^{19}$ This is in addition to the declaration on friendly relations i.e., UN Declaration on the Inadmissibility of Intervention in the Domestic Affairs of States and the Protection of Their Independence and Sovereignty which prohibits states from using or encouraging the use of economic or political methods to coerce other states. ${ }^{20}$ Measures aimed at intruding into a nation's political structure or the integrity of its territory is considered illegal. ${ }^{21}$ In addition, considering the two international bill of rights, which stressed the right of all peoples without restrictions to work towards their economic, social and cultural progress, it will be hard to justify any such coordinated measures. ${ }^{22}$ This position is explicit considering the stance of the United Nations General Assembly (UNGA) in the Charter of economic rights and duties of states. Specifically, the requirement provides: "No State may use or encourage the use of economic, political or any other type of measures to coerce another State to obtain from it the subordination of the exercise of its sovereign rights." ${ }^{23}$ Bearing in mind the overwhelming support of states while

18 Ibid. 209.

19 Ibid. 209.

20 United Nations General Assembly, "Declaration on Principles of International Law Concerning Friendly Relations and Co-Operation among States in Accordance with the Charter of the United Nations" (New York, 1970), www.un-documents.net/a25r2625.htm (last visited 21/11/2017). principle 3.

21 Ibid.

22 UN General Assembly, "International Covenant on Civil and Political Rights" (United Nations, Treaty Series, vol. 999, p. 171, 1966).; UN General Assembly, "International Covenant on Economic, Social and Cultural Rights" (United Nations, Treaty Series, vol. 993, p. 3, 1966), http://www.refworld.org/docid/3ae6b36c0.html [last visited 30 November 2017].

23 UN General Assembly, "Charter of Economic Rights and Duties of States: Resolution / Adopted by the General Assembly, 17 December" 
adopting the charter, it represents their view that economic and political pressures are illegal. Brazen use of economic sanctions to influence the policies of a sovereign state recalling the debates during the Arab oil embargo and its position under the UN Charter. ${ }^{24}$ With respect to the blockade of Qatar however, it is an attempt to influence a state's policy, and to coerce it into surrendering its sovereignty. Economic and political force aside, cross-frontier expulsion of populations has also been considered as use of force. ${ }^{25}$ Nonetheless, whether the use of economic and political coercion falls under the broad definition of article 2 (4) or not, it may amount to an illegal act. $^{26}$

Because article 2 (4) prohibits the use, as well as threat of force, the issuance of ultimatums to comply with certain requirements or face the consequence has been held to amount to a threat of force. ${ }^{27}$ Certainly, requiring a nation to navigate specified political or economic paths' were given as clear examples of such threats considered contrary to article 2 (4). ${ }^{28}$ Thus, the ultimatum given to Qatar and the words used by the blockading nations could, at the least, amount to a threat of force. Qatar was specifically requested to comply with the 13-point ultimatum or "face unspecified consequences". ${ }^{29}$ Such statements may amount to a threat of force as

(A/RES/39/163, 1974), http://www.refworld.org/docid/3b00eff474.html [ last visited 30 November 2017]. Art. 32.

24 See Jordan J. Paust and Albert Blaustein, "The Arab Oil Weapon - A Threat to International Peace," American Journal of International Law 68, no. 3 (1974): 410-39.

25 Randelzhofer and Dorr, "Article 2 (4)." 210.

26 Nigel White and Ademola Abbas, "Countermeasures and Economic Sanctions," in International Law, ed. Malcolm D Evans, 3rd ed. (Oxford: Oxford University Press, 2010), 531-58. 547.

27 ICGJ, Guyana v Suriname, Award, Permanent Court of Arbitration [PCA] (2007). paras. 439 and 445.

28 I.C.J. Reports, Legality of the Threat or Use of Nuclear Weapons, Advisory Opinion (1996). 226, Para 47.

29 The Guardian, "Qatar given 10 Days to Meet 13 Sweeping Demands by Saudi Arabia." 
defined by the ICJ and the Permanent Court of Arbitration (PCA) in the cases cited above. ${ }^{30}$

\section{NON-INTERVENTION IN THE DOMESTIC AFFAIRS OF A STATE}

Considering the powers yielded by the UN on its members, it is necessary to protect the interests of all states. The principle of nonintervention was thus entrenched as a core value of contemporary international law. ${ }^{31}$ This was meant to warrant the sovereignty of states while safeguarding the communal interests. The principle therefore, reflects an essential feature of the affiliation between the UN and member states, as well as among members inter se. Thus, article 2 (7), despite its wordings, ${ }^{32}$ symbolizes the principle in general as it relates to inter-state relationships. ${ }^{33}$ This means that nonintervention is intrinsically tied to the principles of sovereign equality of states and also the proscription on resort to force. ${ }^{34}$ Noninterference may not necessarily translate into unconditional control

30 Guyana $v$ Suriname Award, Permanent Court of Arbitration [PCA] (2007).; Legality of the Threat or Use of Nuclear Weapons, Advisory Opinion (1996).

31 Kawser Ahmed, "The Domestic Jurisdiction Clause in the United Nations Charter: A Historical View," Singapore Yearbook of International Law 10 (2006): 175-97. 175.

32 On this line of argument, see Benedetto Conforti and Carlo Focarelli, The Law and Practice of the United Nations, 4th ed. (Leiden: Martinus Nijhoff Publishers, 2010).156.

33 Dominic McGoldrick, "The Principle of Non-Intervention: Human Rights," in The United Nations and the Principles of International Law, ed. Vaughan Lowe and Colin Warbrick (Abingdon: Rawat Publications, 1994), 88. See also ICJ Reports, Case Concerning military and Paramilitary Activities in and Against Nicaragua (Merits), 14. Para 202.

34 See United Nations, "Charter Of The United Nations." Articles 2 (1) and (4). 
over internal matters $;{ }^{35}$ it certainly means freedom within the confines of the law. ${ }^{36}$

The non-intervention principle was meant to ensure freedom of states to decide on matters within their domestic jurisdiction, especially cultural, economic and social issues. ${ }^{37}$ This inevitably translates into freedom to decide which foreign policies it wants to pursue and the partners it would like to interact on any such issues. ${ }^{38}$ The classical relationship between intervention and the use of force notwithstanding, contemporary international law acknowledge the presence of intervention even without resorting to armed force. ${ }^{39}$ Hence, it would be deemed an intervention, where there is interference, a threat, or even an attempt to interfere in the sovereignty of the state. ${ }^{40}$ In line with the declaration on friendly relations, and decisions of the ICJ, contemporary international law clearly recognises as illegal, any attempt by one state to interfere in the exercise of any of the elements of another nation's sovereignty. ${ }^{41}$ Such elements are clearly reflected in both the declaration on friendly relations and inadmissibility of intervention in the activities of states.

As a result, any coercive attempt to influence the decisions of a state with respect to matters within its sovereign rights amounts to interference in its jurisdiction. Such matters inevitably include the freedom of a state to take decisions relating to its choice of political,

35 Ahmed, "The Domestic Jurisdiction Clause in the United Nations Charter: A Historical View." 176.

36 Georg Nolte, "Article 2 (7)," in The Charter of the United Nations, ed. Bruno Simma et al., 3rd ed. (Oxford: Oxford University Press, 2012), 280-312.283.

37 Ibid. 285. See also ICJ Reports, Case Concerning military and Paramilitary Activities in and Against Nicaragua (Merits), 108.

38 See UN General Assembly, "Declaration on the Inadmissibility of Intervention in the Domestic Affairs of States and the Protection of Their Independence and Sovereignty" (A/RES/2131(XX), 1965).

39 Nolte, "Article 2 (7)." 285.

40 See United Nations General Assembly, "Declaration on Principles of International Law Concerning Friendly Relations and Co-Operation among States in Accordance with the Charter of the United Nations."

41 See for example, ICJ Reports, Case Concerning Military and Paramilitary Activities in and Against Nicaragua (Merits), 14. 107, para 205. 
cultural, economic, and social systems, including its directions on foreign policy. ${ }^{42}$ There is no doubt that the primary purpose of the non-intervention principle is to safeguard the sovereignty and free will of states. ${ }^{43}$

\section{Matters under the domestic jurisdiction of states}

This issue will be considered from at least two basic perspectives: from the perspective of article 2 (4) and the history behind it and from the viewpoint of customary international law. Clearly, the provisions of article 2 (7) was meant to achieve the objective of not only curbing the powers of the UN, but also to reassure other states that the organisation will not be used to invade their sovereignty. Though the term "domestic jurisdiction" was also used in the Covenant of the League of Nations, the context and objective may not be the same. That notwithstanding, the definition proffered under the League of Nations regime offers valuable insight. Consequently, the Permanent Court of International Justice (PCIJ)'s verdict in the Nationality case is apposite. It was held that matters are within a state's domestic jurisdiction where the state has no international obligations of any kind in relation to such matters. That it relates to issues which are not in principle controlled by international law. ${ }^{44}$ It follows therefore that in the absence of an international obligation arising from treaty or customary international law, a state is free to take decisions on matters that concern its sovereign existence. As customary international law applies to the entirety of nations alike, obligations apply to all states alike. In relation to treaty obligations, it certainly rests with the states claiming the existence of any such obligations to identify the treaty in question. States do not have restrictions placed on them in relation to dealing with their citizens, the way their

\footnotetext{
42 Ibid.

43 Nolte, “Article 2 (7)." 289.

44 PCIJ reports, Nationality Decrees Issued in Tunis and Morocco, (Advisory Opinion No. 4) (1923). 7.
} 
government is structured, or actions relating to the use of their territories. ${ }^{45}$

\section{THE BLOCKADE OF QATAR AS USE OR THREAT OF FORCE}

The preservation of global peace and security constitutes the foremost objective of the UN. ${ }^{46}$ To achieve such an objective, the threat and use of force among other things were proscribed. ${ }^{47}$ Seen from this perspective, the prohibition is targeted at all uses of force that may jeopardize universal harmony and safety. The extent of the prohibition is clearly stated: "against the territorial integrity or political independence of a state, or in any other manner inconsistent with the Purposes of the Charter". ${ }^{48}$ Thus, any action that amounts to force, once applied or threatened to be applied "against the territorial integrity or political independence of a state" falls under the prohibition. Moreover, where such an action contravened the purpose of the UN, it also falls under the proscription in article 2 (4). The purpose of the UN include tolerance, good neighbourliness, maintenance of international peace and security, prohibition of the use of force, and the promotion of economic and social advancement of all people. ${ }^{49}$ The actions of the blockading nations on Qatar are inconsistent with the objectives of the United Nations as clearly defined by the Charter. The coordinated blockade is aimed at invading the sovereignty and political independence of Qatar by imposing on it, conditions amounting to a surrender of its sovereign rights to the blockading nations. The blockade was meant to harm, if not suffocate Qatar's economy and social advancement. This approach is necessary because the dividing line between forcible and non-forcible measures has always been thin. ${ }^{50}$ Because nations have

45 Conforti and Focarelli, The Law and Practice of the United Nations. 159.

46 United Nations, "Charter Of The United Nations." Art 1 para 1.

47 Ibid. art 2 para 4.

48 Ibid.

49 Ibid. preamble, para 2.

50 Lori Fisler Damrosch, "Politics Across Borders: Nonintervention and Nonforcible Influence over Domestic Affairs," The American Journal of International Law 83, no. 1 (1989): 1-50. 4. 
come to rely more on economic rather than political strength, this line has become even thinner. The influence of states today is measured through the economic status and wellbeing of its citizens. Hence, any coordinated move aimed at crippling a state's economy amounts to an application of might contrary to the objects of the United Nations, because it imperils international stability. ${ }^{51}$

In analysing the blockade of Qatar in relation to the threat or use of force, it is essential to bear certain fundamental issues in mind. First, the coordination of the blockade by several nations mostly sharing borders and important conduits such as sea and airspace with Qatar. Second is the nature of the demands which require Qatar to surrender its sovereign rights without corresponding obligations from the other parties. Third is the fact that no breach of international law or international obligation was seriously raised against Qatar. The coordinated blockade against Qatar having been orchestrated by several nations without justification in international law nor claim to international wrongfulness, is unique. It is unique because of the coordination by several states to cripple the nation's economy, intimidate and overwhelm its citizens, and eventually reverse its prosperity. This certainly infringes the purpose of the United Nations. Like the Arab oil embargo, its planning and execution is spectacular as it is multi-faceted. While the Arab oil embargo was mainly economic in nature, and aimed at addressing an international issue, the blockade of Qatar is multi-dimensional and aimed at eroding the sovereignty of a single state. Hence, if the Arab oil embargo contravened article 2 (4), ${ }^{52}$ the blockade on Qatar is even worse in that respect.

Though several kinds and stages of pressure in day-to-day interactions among states may be tolerated, the choice of forcible policies is certainly restricted by the lawfulness of the objectives

51 Michael N. Schmitt, "Computer Network Attack and the Use of Force in International Law: Thoughts on a Normative Framework," Colum. J. Transnat'l L. 37 (1999): 885-938. 900.

52 Paust and Blaustein, "The Arab Oil Weapon - A Threat to International Peace." 439. 
pursued and real effects in communal course. ${ }^{53}$ The most important issue around the prohibition in article 2 (4) is the seeming restriction: "...territorial integrity or political independence, or in any other manner inconsistent with the Purposes of the Charter". It follows that actions calculated to impugn these principles are plainly prohibited. In addition, even where such actions do not target the sanctity of the nation's territory, nor the choices of its political entity, they remain prohibited so long as they breach the objectives of the UN as stated above. Extending the scope of the prohibition to actions which are "in any other manner inconsistent with the Purposes of the United Nations", ${ }^{4}$ incorporates effectively all forceful measures not sanctioned under the Charter. ${ }^{55}$

Consequently, the legitimacy of any forceful measure needs to be founded in the Charter, otherwise it is unlawful. This is more the case considering the peremptory standing of the prohibition against resort to force ${ }^{56}$ It is true that what matters the most here is whether the action amounts to force; and true, the meaning of force has been debatable over the years. The exact limits of the Charter's proscription of resort to force is therefore, based on the activity in question. If it amounts to force, then it must be established as one of the exceptions enunciated in the UN Charter. ${ }^{57}$ Having said that, the Charter having been drafted decades ago, must be articulated in line with its objectives to regulate contemporary realities with necessary vicissitudes. As stated above, the definition of a nation's strength in the 1940s when the Charter was drafted has changed considerably. Today, the economic prosperity of a state determines its strength just as demonstrated by the growing relevance of China because of its economic prowess. This being the case, the implications of coordinated attempts to asphyxiate the economic advancement and relevance of a state in contemporary days is more perilous to the state than it would have been seventy years ago. It is therefore necessary

53 Jordan J Paust and Albert P Blaustein, "The Arab Oil Weapon: A Reply and Reaffirmation of Illegality," Columbia Journal of Transnational Law 15, no. 1 (1976): 57-73. 58.

54 United Nations, "Charter Of The United Nations." art.2 (4).

55 Schmitt, "Computer Network Attack and the Use of Force in International Law: Thoughts on a Normative Framework." 901.

56 Randelzhofer and Dorr, "Article 2 (4)." 207.

57 Ibid. 208-9. 
that each threat or use of force is assessed considering the precise evidence and the framework within which it transpired ${ }^{58}$ because the classes have evolved. The final assessment of the legality of an action must be synergised with the cruelty and imminence of the situation as well as the alternatives and viability of responses. Therefore, it may not be practicable to carry out an analysis of the Charter divorced of the continuously developing realities. It is thus apposite to understand the provision of article 2 (4) as a wide-ranging prohibition on the use of force. This way, some forceful acts that might have seemed outside the thin choices offered by the Charter nonetheless comport to the wider definition. ${ }^{59}$

\section{THE BLOCKADE OF QATAR AS INTERFERENCE IN INTERNAL MATTERS OF A NATION}

The tenet of non-interference in the domestic affairs of states echoes the principle of state sovereignty. A state's sovereignty is determined by its ability to govern its territory and take decisions without foreign interference. ${ }^{60}$ Hence, non-intervention is primarily meant to safeguard order and peaceful synchronicity between states; it constitutes a core rule of inter-state relationship. ${ }^{61}$ To deal with the logic of lawlessness inherent in international relations, it is required that states respect the boundaries of other states. The principle therefore, is not merely a technical and legalistic formulation. It symbolises one of the rudimentary philosophies of the UN. ${ }^{62}$ The domestic jurisdiction of a state symbolises its right and freedom to exercise its actions relating to statecraft without intrusion by other

58 W. Michael Reisman, "Criteria for the Lawful Use of Force in International Law," Yale J. Int'l L. 10 (1985): 279. 281.

59 Schmitt, "Computer Network Attack and the Use of Force in International Law: Thoughts on a Normative Framework." 904.

60 Ambrina Khan, "Principle of Non-Intervention and Non-Use of Force: Customary Norm with Changing Interpretations," International Journal of Socio-Legal Analysis and Rural Development 3, no. II (2015): 11725.118.

61 Ibid. 117.

62 Ahmed, "The Domestic Jurisdiction Clause in the United Nations Charter: A Historical View." 182. 
states and international organisations as an embodiment of its sovereignty. ${ }^{63}$

It is true that the tenet of non-interference in the domestic matters of a nation were initially designed to limit the powers of UN agencies in dealing with states. Having said that, there is no doubt that the principle has become applicable to all forms of intervention or interference by other states. Thus, a state would be interfering with the internal matters of another nation where it influences or attempts to influence issues ordinarily considered within the preserve of a state's exercise of sovereignty. Classically, it is considered as intervention where the action consists of "dictatorial interference" with domineering compression. ${ }^{64}$ Comparing the facts surrounding the blockade of Qatar, nothing can be more dictatorial and domineering than the way the sovereign state of Qatar was given specific instructions on how to run its domestic and foreign affairs. Most of the 13-point demands specifically mandated Qatar to take explicit actions in terms of its foreign relations such as requiring it to expel Turkish troops, and to scale back its relationship with Iran. ${ }^{65}$ Clearly, nothing can be more dictatorial and overbearing than an ultimatum given to a sovereign state by other sovereigns telling it which states to relate with. Indeed, it is not only being dictated to on which states to relate with, but also on the specifics of the relationship it should have with such states, including the closure of its diplomatic missions. At the same time, Qatar was instructed to develop economic and other relations with the Gulf states without them reciprocating in return.

Moreover, demanding that the state of Qatar closes the AlJazeera news agency without even attempts at justifying why such a move was necessary for the common good of the region was exceptionally overbearing. ${ }^{66}$ What could be bossier than dictating to a

\footnotetext{
63 Ibid. 183.

64 Hersch Lauterpacht, "The International Protection of Human Rights," Recueil Des Cours de l'Académie de Droit International de La Haye 70, no. 1 (1947): 1. 19, as cited in Ahmed, "The Domestic Jurisdiction Clause in the United Nations Charter: A Historical View." 183.

65 See The Guardian, "Qatar given 10 Days to Meet 13 Sweeping Demands by Saudi Arabia."

66 Ibid.
} 
sovereign state which institution should be operating within its territory? At the same time, Qatar was instructed on which foreign nations it should partner with. The existence of the media and the level of freedom they enjoy is clearly a matter of national values. Accepting the sweeping demands would no doubt effectively end Qatar's independent foreign policy. ${ }^{67}$ The 13-points demand by the Saudi-led group is perhaps the most outrageous desecration of the tenet of non-interference witnessed in recent years. Interference either armed or otherwise are clearly illegal within the meaning of the Charter as interpreted by the UNGA. ${ }^{68}$ The wordings from the first paragraph of resolution 2131 of 1965, undoubtedly signposts the focus of the resolution. It shows that the international community was concerned about "armed intervention and other direct or indirect forms of interference threatening the sovereign personality and the political independence of States". ${ }^{69}$ This concern underlies the move by the UNGA to determine the unlawfulness of such actions in present-day international law. Therefore, the tenet, as adumbrated in the resolution, was reflective of the general and overriding views of nations as to the position of international law. This can be seen from two important indicators: first, the overwhelming votes with which the resolution passed through the UNGA. Secondly, as clearly captured in the resolution it reflects the position of nations in several fora including the Charters of the Organization of the American States (OAS), the League of Arab states and the Organization of African Unity (OAU) to mention a few. ${ }^{70}$ This being the case, the unlawfulness of interference is something that the blockading nations themselves have for long recognised.

Following up on this position is the Declaration on principles of friendly relations which in strong language, reaffirmed the

67 Ibid.

68 See UN General Assembly, "Declaration on the Inadmissibility of Intervention in the Domestic Affairs of States and the Protection of Their Independence and Sovereignty", A/RES/20/2131, $\left(21^{\text {st }}\right.$ December 1965)."

69 Ibid. preamble, para 1.

70 Ibid. preamble, para 5. 
illegality of intervention. ${ }^{71}$ In fact, the 1970 declaration outlines what amounts to intervention in the domestic or foreign businesses of another nation. Among other things, "... all other forms of interference or attempted threats against the personality of the State or against its political, economic and cultural elements, are in violation of international law." 72 The actions, in addition to demands of the blockading states could not have been captured better than what is contained in this 47-year-old document. The blockading of sea and airspace, the coordinated cutting of political and trade activities, in addition to issuing bossy and sovereignty-invading demands, certainly amount to threats and interference against the personality of the state of Qatar. Moreover, applying, or encouraging the application of "economic, political, or any other type of measures to strong-arm another nation to acquire from it the subservience of the exercise of its sovereign rights and to secure advantages of any kind" are unlawful. ${ }^{73}$ In this line, the severance of diplomatic and trade ties with Qatar, in addition to blocking it from the use of airspace and seaports constitute resort to political, economic and additional measures. Of course, the aim of which is to obtain from the state of Qatar, a subordination of its sovereign rights and advantages as clearly stipulated by the terms of the 13-point demands.

\section{THE 13-POINTS DEMANDS: FORCE OR INTERVENTION?}

The high point of the coordinated blockade of Qatar was the issuance of a 13-point demand by Saudi Arabia and its allies, requiring Qatar to abide by the terms of the demands within ten days, or face isolation. ${ }^{74}$ First on the list of the demands is the shaping of Qatari foreign relations with Iran: that Qatar should put an end to diplomatic interaction with Iran, including the shutting down of all consular

71 United Nations General Assembly, "Declaration on Principles of International Law Concerning Friendly Relations and Co-Operation among States in Accordance with the Charter of the United Nations" A/RES/25/2625 (24 $4^{\text {th }}$ October 1970)".

72 Ibid. The principle concerning the duty not to intervene in matters within the domestic jurisdiction of any State, in accordance with the Charter.

73 Ibid.

74 The Guardian, "Qatar given 10 Days to Meet 13 Sweeping Demands by Saudi Arabia." 
workplaces in Iran. It also requires Qatar to stop combined military trainings with Iran and eject all Iranian military personnel from its territory. Moreover, trade and commerce between Qatar and Iran should be subjected to the international and United States of America (USA) sanction regime against Iran. ${ }^{75}$ The implication of this first demand is that Qatar must subject its sovereignty to Saudi Arabia and its allies. Clearly, the most important feature of a modern state is its sovereignty in terms of regulation of its foreign policy. ${ }^{76}$ This naturally includes the decision on which states to deal with within the confines of international law. Sovereignty implies the liberty of all nations in shaping their own purpose and interactions in the comity of nations. ${ }^{77}$ This element goes hand in hand with the way states treat one another, including their territory and citizens. ${ }^{78}$ Definitely, that sovereignty translates into Qatar deciding on which members of the community it wants to relate with, and the exact nature of such relationships, so long as it stays within legal limits. Joint military training is a common feature of modern-day defence strategies carried out by several nations across all corners of the globe. These exercises disclose a lot regarding what lie beneath a nation's international dealings, as states take part in them for quite a lot of motives, in addition to the advantages they present. ${ }^{79}$ Unilaterally demanding that Qatar seize such activities therefore, inherently threatens its security and safety. The national security of a nation on the other hand, should be its primary concern - something it cannot easily relinquish. ${ }^{80}$ Indeed, it is the bedrock of its sovereignty which it will always jealously protect.

76 US Diplomatic and Consular Staff in Tehran case, ICJ Reports, 1980, p. 3, 40.

77 Ronzitti, Natalino. "Respect for Sovereignty, Use of Force and the Principle of Non-intervention in the Internal Affairs of Other States." European Leadership Network (2015), 1.

78 Ibid.

79 D’Orazio, Vito. "Joint Military Exercises." (2013); http://www.vitodorazio.com/uploads/1/3/0/2/13026085/jmes.pdf; 1, (last visited 05/08/2018).

80 See, Jepperson, Ronald L., Alexander Wendt, and Peter J. Katzenstein. "Norms, identity, and culture in national security." The culture of national security: Norms and identity in world politics 33 (1996): 34. 
Consequently, the decision on whether one state should maintain its presence in another state by way of establishing its missions abroad can only be made by the state and its host state. ${ }^{81}$ One sovereign state demanding another sovereign state to sever consular relations with a third state is the height of audacity in international law. It is even more unacceptable where the only reason is Saudi Arabia's animosity with Iran which clearly has nothing to do with Qatar. But then, is this a forceful measure or interference in the domestic affairs of Qatar? This question may be answered by looking at the nature of the demands, the language used, and the possible consequences where the demands are not met. From the language, Qatar was required to meet up with the demands or face the consequences, suggesting unpalatable penalties. Whether those consequences would involve the use of force or not, is not relevant here. What is relevant is that Qatar, as a sovereign state, felt threatened by the actions and demands of its neighbours who have what it takes to undermine its sovereignty. This follows from the fact that the essence of the prohibition against the use of force is to safeguard the right of states. ${ }^{82}$ Clearly though, no forceful measure was threatened, nor could it be a likely consequence, at least if economic coercion is not considered as force. Having said that, it is noteworthy that even those who do not consider economic and political coercion as force accommodated the notion that encouragement or provocation of force forms part of the prohibition. ${ }^{83}$ If on the other hand, economic and political coercion are considered as force, then, considering the economic and political measures already imposed on Qatar by its neighbours, there was a forceful action. The position of this article though, is that the drafting history of article 2 (4) and the subsequent state practice does not support the notion that economic and political coercion formed part of the prohibition. ${ }^{84}$ Because this particular term of the " 13 points demands" require Qatar to submit a matter within its internal affairs to the

81 First Fidelity Bank NA v. Government of Antigua and Barbuda Permanent Mission 877 F.2d 189 (1989); 99 ILR, p. 125.

82 Edward Gordon, "Article 2(4) in Historical Context", Yale Journal of International Law, 10, No. 2 (1985); 271-278, 272.

83 Derek W. Bowett, "Economic Coercion and Reprisals by States" Virginia Journal of International Law, 10 (1972) 1-12, 2.

84 See Randelzhofer and Dorr, “Article 2 (4)," 207-209. 
discretion of its neighbours however, it amounts to an interference in its domestic jurisdiction. This is the clear wordings of the UNGA declaration of 1970 which forbade states from using or enabling the use of economic or political actions to strong-arm another nation with the aim of rendering it subservient. ${ }^{85}$ The same argument goes for the fifth item on the list of demands, which requires Qatar to discontinue military collaborations and exercises with Turkey, including activities taking place inside Qatar's territory.

Second on the list of the demands issued to Qatar is that it should end all relationships it has with terrorists' organisations. On the face of it, this demand is the least controversial of all the issues raised considering the global need to fight terrorism. Clearly, there is nothing wrong in insisting that a state should sever ties with terror groups which are responsible for violence and insecurity in the region. Indeed, such a request would have the backing of the United Nations Security Council (UNSC) considering measures it has taken in relation to the issue of terrorism. Over the years, the UNSC has adopted several resolutions on the international fight against terrorism. Some of these measures were given the strongest backing of the Council, requiring states to take specific actions against terrorist organisations. ${ }^{86}$

Having said that, it is one thing to demand that a state must abide by the United Nations Security Council (UNSC) resolutions on terrorism, and it is another thing altogether when it is required to comply with the domestic laws and policies of other sovereign states. There is no doubt that groups such as Al-Qaeda and ISIS have been designated terrorists' organisations by the UNSC. As such, there is nothing wrong in insisting that Qatar should sever all ties to them; indeed, it is bound to act based on the UNSC resolutions to that

85 G.A. Res. 2625, 25 U.N. GAOR, Supp. 28, at 123, U.N. Doc. A/8082 (1970).

86 From September 11, 2001 to December 2017, the UNSC has adopted more than 30 resolutions on terrorism and related matters, including Resolution 1368 (2001), Resolution 1373, 1377, 1388, 1390, 1452, 1455, 1456, 1566, 1624, 1730, 1735, 1787, 1988, 1989, 2055, 2082, $2083,2133,2161,2170,2178,2195,2199,2249,2309,2322$, and many more. 
effect. However, the designation of other groups such as the Muslim Brotherhood and Hezbollah as terrorists' organisations is a matter of national policy since the international community has not reached such an understanding. It is no secret that one of the primary obstacles to the international efforts to fight terrorism is the lack of generally accepted definition of terrorists. ${ }^{87}$ Consequently, whether the Muslim brotherhood and Hezbollah are terrorist organisations within the international legal framework on terrorism is doubtful. As a result, those states that designate them as such within their national legal or policy framework have their reasons for doing so. Further, those states who consider them national liberation movements do so based on their understanding of the international legal framework. It would therefore be bizarre for some states to insist that another sovereign nation must fashion its foreign policy and national legal framework after their own. This clearly amounts to an interference within the internal affairs of a state. Therefore, the conflation of members of these groups with terrorism or extremism demonstrates a perilous pattern aimed at providing the necessary excuse for these regimes to clampdown on peaceful Islamic groups. ${ }^{88}$ But then, whether Qatar supports terrorism can only be determined by looking at the precise definition of terrorism, and the sort of Islamic ideology considered politically suitable for the Gulf states. ${ }^{89}$ Demanding that Qatar cease financial support to all persons or groups designated as terrorists by the USA, and the four blockading nations, as contained in the sixth term of the demands is also covered by the argument here.

Again, whether Qatar can legitimately be required to arrest and transfer certain individuals labelled "terrorists" or wanted persons to any of the blockading nations will depend on its laws and international legal instruments it is a party to, rather than domineering

87 See Saul, Ben. "Definition of "terrorism" in the UN Security Council: 1985-2004." Chinese Journal of International Law 4, no. 1 (2005): 141 166. Also, Saul, Ben. "Attempts to define 'terrorism' in international law." Netherlands International Law Review 52, no. 1 (2005): 57-83.

88 Freer, Courtney: Social Effects of the Qatar Crisis. In: IndraStra Global (2017), 10, URN: http://nbnresolving.de/urn:nbn:de:0168-ssoar-541134, 3: (Accessed 13/08/2018).

Ibid. 
demands. ${ }^{90}$ As a sovereign state, Qatar is entitled to decide on who is categorised a terrorist, and to whom it grants political asylum to stay within its frontiers. ${ }^{91}$ This is an integral part of the definition of a nation's sovereignty reflected in its ability to regulate issues relating to the use, entry, and living within its territory. ${ }^{92}$ To coerce a sovereign state into accepting a legal or policy position of another state, without recourse to international law is clearly an attempt to subject its laws and sovereignty to that of those other states. ${ }^{93}$ The seventh demand of the blockading nations amounts to an interference in the domestic affairs of a sovereign state. A better way to achieve this would have been to propose a regional instrument among the Gulf cooperation Council (GCC) states, and then influence Qatar in a civilised manner to join it. That would clearly be a matter of cooperation between sovereign states, aimed at securing their collective security.

As part of the 13-points demands, Qatar was also required to close Aljazeera and other television stations it allegedly funds. These stations are seen by the blockading nations as an instrument used by Qatar to exert enormous influence in the gulf and to drive propaganda clearly incompatible with their view of things. ${ }^{94}$ It is probably true that Al Jazeera for example, has engaged in a biased reportage of events in the Gulf region, aligning itself with the interests and foreign policies of Qatar. ${ }^{95}$ This in turn, might have ignited genuine concern or even fear in the leaders of the blockading nations regarding the security of their own states, especially considering the realities of the

90 See Shearer, Ivan Anthony. Extradition in international law. Manchester University Press, 1971.

91 See Gibney, Matthew J. The ethics and politics of asylum: Liberal democracy and the response to refugees. Cambridge University Press, 2004.

92 Boed, Roman. "The state of the right of asylum in international law." Duke J. Comp. \& Int'1 L. 5 (1994): 1, 3-4.

93 Slaughter, Anne-Marie. "International law in a world of liberal states." European Journal of International Law 6, no. 3 (1995): 503-538, 506-8.

94 The Economist, 'Why Al Jazeera is under threat' Jul 1st 2017, Cairo, https://www.economist.com/middle-east-and-africa/2017/07/01/why-aljazeera-is-under-threat, (Accessed 14/08/2018).

95 Ibid. 
Arab spring. As a result, these states could have genuine reasons to take measures aimed at protecting their national security and interests. ${ }^{96}$ Having said that, requesting Qatar to shut-down the news outlets, without verifiable wrongs in international law does not look so appealing to neutral observers considering the glorified support a free media enjoys in contemporary global realities. The best option would rather be for the states which have reasons to worry about the activities of these news outlets to block the stations from broadcasting in their territories. ${ }^{97}$ This at least, is something within their domestic jurisdiction, and cannot amount to meddling in another state's sovereign rights.

In as much as the eighth mandate on the 13-points list is a legitimate one, it is also the most satirical. Qatar was required to stop interfering in the internal businesses of other states via an instrument and measures that are themselves the height of intervention in its own internal matters. ${ }^{98}$ It is true that citizenship is an extremely delicate subject; not the least because it demonstrates the sovereign status of a state as a distinct entity. Predictably, disagreements around nationality do lead to strain and scuffle, equally inside and amongst nations. ${ }^{99} \mathrm{Be}$ that as it may, the decision whether to naturalize or not is that of the individual in question; until such a time, they go on as nationals of their state of origin. Yet, even at that time, their state of abode can exercise its territorial authority over them. As far as international law is concerned, their attachment to their state of origin establishes the right to go back and protect their state while abroad. ${ }^{100}$

96 See Wolfers, Arnold. "" National security" as an ambiguous symbol." Political Science Quarterly 67, no. 4 (1952): 481-502.

97 See Anderson, Terry. "Terrorism and censorship: the media in chains." Journal of International Affairs (1993): 127-136. Also, Bamman, David, Brendan O'Connor, and Noah Smith. "Censorship and deletion practices in Chinese social media." First Monday 17, no. 3 (2012).

98 See the details of the 13-points Demand among which were bossy demands clearly aimed at eroding Qatar's sovereignty. The Guardian, "Qatar given 10 Days to Meet 13 Sweeping Demands by Saudi Arabia."

99 UNHCR-a, Poviiest. "Nationality and statelessness: A handbook for Parliamentarians." (2005), 8.

100 Bauböck, Rainer. "Towards a political theory of migrant transnationalism." International migration review 37, no. 3 (2003): 700723,702 . 
Questions relating to citizenship are in principle within the domestic jurisdiction of states. Yet, measures taken by states must avoid conflict with the nationality laws and policies of other states, and international law. ${ }^{101}$ This in essence, was the position advocated by the PICJ, when it remarked that: "The question whether a certain matter is or is not solely within the domestic jurisdiction of a State is an essentially relative question; it depends on the development of international relations." 102 This position could be seen vividly reflected in the Hague Convention of 1930, section 1 of which reiterated the principle that citizenship is within the domestic jurisdictions of states, though they should exercise it in line with international law and custom. ${ }^{103}$ However, the contemporary practice in terms of a second nationality or the right of an individual to change his nationality has gone more in line with the provisions of article 15 of the Universal Declaration of Human Rights (UDHR). ${ }^{104}$ This provision, often accepted as having crystalized into a rule of jus cogens, protects the right of all persons to a nationality, including the right to change their nationality. This being the case, though Saudi Arabia and its allies can decide not to recognise dual citizenship, Qatar is also entitled to grant its nationality to those who need it under its domestic laws. ${ }^{105}$ This is more the case where such individuals living in Qatar are asylum seekers who are likely to be persecuted or face human rights related abuses in their home country.

101 UNHCR-a, Povijest. "Nationality and statelessness:8.

102 See Advisory Opinion No. 4, Nationality Decrees Issued in Tunis and Morocco, 4, Permanent Court of International Justice, 7 February 1923, available at: http://www.refworld.org/cases,PCIJ,44e5c9fc4.html [accessed 16 August 2018].

103 League of Nations, Convention on Certain Questions Relating to the Conflict of Nationality Law, 13 April 1930, League of Nations, Treaty Series, vol. 179, p. 89, No. 4137, available at: http://www.refworld.org/docid/3ae6b3b00.html [accessed 16 August 2018]. See also The Asylum Case (Colombia v. Peru) ICJ Reports, (1950), 266.

104 UN General Assembly, Universal Declaration of Human Rights, 10 December 1948, $217 \quad$ A (III), available at: http://www.refworld.org/docid/3ae6b3712c.html [accessed 16 August 2018].

105 Asylum Case (Colombia v. Peru) ICJ Reports, (1950), 266, 278. 
For the ninth demand which requires that Qatar cease interaction with political oppositions in the blockading nations, it is a legitimate demand, considering that if such actions were true, it might amount to interference in the internal issues of these nations. Hence, if Qatar was really involved in such activities, this demand amounts to a call by its neighbours, that it should desist from such interference. It is true that states engage in activities such as support for opposition and other groups; that however, does not justify it in law. ${ }^{106}$ The tenth demand which requires reparation for the wrongs done by Qatar is also fair, especially that it would be determined in harmonisation between the states: so long as such wrongs are truly established. ${ }^{107}$ Again, the $11^{\text {th }}, 12^{\text {th }}$, and $13^{\text {th }}$ demands are rather nebulous and dictatorial, as they lack justification in law.

Some of the demands contained in the 13-points Demands might be valid in law, especially if the allegations were to be established. However, most of the demands are clear cases of interference in the internal affairs of Qatar. Interestingly, the blockading countries are also accusing Qatar of interference in their internal matters. Having said that, the question is why didn't the blockading nations take their case before the ICJ? One would have expected that such a measure would have been the most appropriate response, especially to preserve international peace and security.

For the use of force however, the 13-points demand aside, more worrisome are the aftermaths of the blockade which might lead to more likelihood of a threat or even use of force among the Gulf states. The mistrust, tension, and uncertainty created by the actions of these states have led to the decision by Qatar to purchase missile defence systems from Russia. ${ }^{108}$ This decision on the other hand, infuriated Saudi Arabia so much that it threatened to use force against

106 See Vincent, Raymond John. Nonintervention and international order. Princeton University Press, 2015.

107 See Falk, Richard. "Reparations, international law and global justice: a new frontier." (2006).

108 Reuters, "Qatar in Talks to Buy Russia's S-400 Systems: Tass" JANUARY 25, 2018, https://www.reuters.com/article/us-russia-qatarmilitary-hardware/qatar-in-talks-to-buy-russias-s-400-systems-tassidUSKBN1FE0HP (Accessed 14/08/2018). 
Qatar if it deploys the Russian made defence system. ${ }^{109}$ The threat coming from Saudi Arabia in this particular instance, violates the prohibition on the threat or use of force under the UN Charter and customary international law. ${ }^{110}$ This is even more so considering that the decision to purchase weapons as the one in contention is solely that of the state wishing to do so, a position reiterated by Qatar. ${ }^{111}$

\section{CONCLUSION}

The blockade of Qatar has raised important issues relating to the proscription against the use of force and the non-intervention principle in international law. In assessing the legal repercussion of the blockade, the history behind the proscription of force is illuminating. The prohibition was meant to ensure peaceful coexistence among states while reassuring smaller and weaker nations of collective protection. The connotation of "force" under article 2 (4) of the Charter may be debatable. However, what is not debatable is the objective of the United Nations as clearly articulated in the Charter. Hence, the proscription of force is specifically tied to the political structure, sanctity of national territory, and the purpose of the United Nations. The debate relating to economic and political coercion as force was conveniently settled by the ICJ in its "advisory opinion on the threat or use of nuclear weapons". Within the context of article 2 (4), threatening a state to take an economic or political path is illegal.

In line with the declaration on friendly relations, the declaration on the inadmissibility of intervention, and the charter on

109 Reuters, "Saudi threatens military action if Qatar deploys anti-aircraft missiles: report" JUNE 2, 2018; https:/www.reuters.com/article/ussaudi-qatar-france/saudi-threatens-military-action-if-qatar-deploys-antiaircraft-missiles-report-idUSKCN1IY0IW (Accessed 14/08/2018).

110 See Legality of use of force (Yugoslavia v Belgium) (Provisional Measures,) ICJ Rep [1999] 124.

111 Al Jazeera, "Qatar FM: 'Impulsive behaviour' is a threat to GCC stability" 05 Jun 2018, https:/www.aljazeera.com/programmes/talktojazeera/2018/06/qatar-fmimpulsive-behaviour-threat-gcc-stability-180604141213105.html (Accessed 14/08/2018). 
economic rights and duties of states, some of the terms of the 13points demanded by Qatar violate international law. They amount to dictatorial intrusion into the domestic matters of a sovereign nation. The clear position of the UNGA in these documents supported by the blockading nations themselves renders some of their actions illegal. Most of the wordings of the 13-points demand by the Saudi-led group could not have been more domineering and bossier. Because most of the demands strive to not only dictate to a sovereign state, but also take away its rights to determine which course it wants to chart for its development and progress, it amounts to clear intervention in its domestic affairs.

Whether the blockade of Qatar amounts to use of force is debatable considering the unending debate on the position of economic and political coercion in relation to the threat or use of force. Without an iota of doubt however, the blockade of Qatar is an interference in the internal matters of a sovereign state, and therefore unlawful. 